\title{
Modeling Equipment Procurement Strategic Decisions Competing for Limited Available Budget under Redundant Accessory Cost
}

\author{
C. O. Osueke ${ }^{1}$, B. O. Akinnuli ${ }^{2} \&$ O. O. Ojo ${ }^{2}$ \\ ${ }^{1}$ Faculty of Science and Engineering, Landmark University, Omu-Aran, Kwara State, Nigeria \\ ${ }^{2}$ School of Engineering and Engineering technology, Federal University of Technology, Akure, Ondo State, \\ Nigeria \\ Correspondence: Basil Olufemi Akinnuli, School of Engineering and Engineering technology, Federal University \\ of Technology, Akure, Ondo State, Nigeria. Tel: 234-803-465-9522. E-mail: ifembola@yahoo.com
}

Received: February 16, 2015

Accepted: October 17, 2015

Online Published: October 19, 2015

doi:10.5539/emr.v4n2p80

URL: http://dx.doi.org/ emr.v4n2p80

\begin{abstract}
The challenges that used to come up as a result of project failure have to do with improper planning. This is looking into future what can occur based on present event. In financing equipment or machinery, the capital in hand is a critical factor that determines equipment procurement strategies. There is need for an optimum model to control the available budget to be put in place in order to optimally allot the available budget to the machines, spare parts and miscellaneous costs under the redundant of accessory cost. This study identified the financial strategic decisions for machines, spare parts and miscellaneous costs, developed mathematical models for the identified strategic decisions, test and evaluate the performance of the developed models. In this study, three strategic decisions were considered (i.e., machines, spare parts and miscellaneous costs) and the optimum model to control the budget for machines, spare parts and miscellaneous costs are dealt with under the redundant accessory cost. This is because an existing manufacturing company or industry has high inventory of accessories which always aid the performance of machine in the industry. Therefore, it is necessary to optimally allot the available budget on the machine(s) to be procured, spare part to be stocked and miscellaneous cost. The amount allotted to machines, spare parts and miscellaneous while budgeting for year 2015 are in this ratio: Machines, $(\$ 5,263.83)$; Spare parts, $(\$ 27,723.09)$; Miscellaneous, $(\$ 4,366.03)$, this based on available small budget of $\mathrm{N}$ $6,350.000$ of dollar value of US $\$ 1,079,500.00$. This model is a strong decision tool for allocating available budget in the period of financial scarcity where equipment procurement for production needs must be carried out. This model is highly recommended to any manufacturing company, small, medium and large scale that equipment procurement affects their production in developed and developing countries.
\end{abstract}

Keywords: modeling, equipment procurement, strategic decisions, available budget, redundant accessory cost

\section{Introduction}

The impact of the production sector of a company on its economic growth cannot be over-emphasized. It is always known that the economic growth of various companies that deal with production in a country will not only affect the nation's economy positively but will also promote the nation to greener pasture. To act as a buffer for boosting the economy of the company and the nation at large, the production sector itself must be operating functionally so that revenue can be generated (Akinnuli, 2008). Akinnuli also stresses that generating revenue requires proper planning of production processes and every process planned depends majorly on the machines to be used in achieving this purpose. Obviously the machines require proper planning since every other production planning depends on them. Machinery planning includes procurement and ensuring that the machines operate in good condition at all time. This is done by making sure that the spare parts accessories are randomly available as at when needed and replacing them when they fail with functional ones (Bolton, 2002). To achieve this, plan has to be made to ensure that these replacements are available that is, it must be in stock in the company's store. For proper planning, forecasting tools would be needed. Osmond (2009) considered the case of budgeting, which is an important part of small business management that budgets serve to limit the amount of expenditures for various economic resources. George (2004) states that many companies use their accounting or finance departments for planning, creating and developing budgetary procedures but smaller or home-based businesses may not have a detailed budget process since less cash is involved in these operations. Two important budgets 
include inventory purchases and personnel decisions were identified by Hayes and Renard (1993). They went further to say that inventory and personnel often represent the two largest expenses organizations have in the business environment.

But Fabrycky (2002) established the fact that inventory is a large expense since companies usually have more on hand than they can sell. This ensures companies do not run out of inventory and face declining sales. Hiring employees is generally an expensive process since companies spend copious amounts of time interviewing and training individuals for various company positions. Osmond (2009) and Bolton (2002) and Brand (1999) also stress that Inventory budgets help companies avoid inventory obsolescence and wasted capital from useless goods.

A budget is a quantitative expression of a plan for a defined period of time. It may include planned sales volumes and revenues, resource quantities, costs and expenses, assets, liabilities and cash flows. It expresses strategic plans of business units, organizations, activities or events in measurable terms (Cliché et al., 2012).

Budgeting has always been part of the activities of any business organization of any size, but formal budgeting in its present form, using modern budgeting disciplines, emerged in the $1950 \mathrm{~s}$ as the numerical underpinning of corporate planning (Dyer et al., 2003). Modern corporate planning owes much to operations research and systems theory (Peter, 2007).

Modern formal budgets not only limit expenditures; they also predict income, profits, and returns on investment a year ahead. They have evolved into tools of control and are also used as a means of determining such rewards as profit-sharing and bonuses (Hunts, 1973). Unless the budgetary process is managed with extreme skill and care, the very virtues of budgeting can turn into negatives - and have, of late, emerged into a movement actively working to change this process (Peter, 2007). It is required to have proper planning in order to avoid project failure. This depends on the present event and the capital in hand need to be considered before forecasting into the future to know the capital required for financing equipment before they are procured as advised by (Hurwicz, 1973). This research revealed how the limited resources available can be optimally allotted to the equipment, spare part, and miscellaneous during procurement, serves as basis to proper planning and to avoid project failure, helps to avoid overbudget and underbudget and also running at lost. The nature of present business environment is such that no organization can boast of having sufficient resources. Similarly, the degree of competition in which the industry is involved signifies the need for achieving high productivity in order to retain its competitive strength. Based on these factors, it becomes mandatory for an organization to ensure its limited resources are put into efficient use. One of the ways of achieving this objective is to determine the organizational financial obligation in advance. This is known as budget preparation (Iwarere, 2007).

\section{Methodology}

In order to identify budget strategic decisions needed to forecast the required cost for the available budget allocation, some companies were visited to know area of strategic decisions, collect previous cost of some machines purchased in their companies as well as that of spare parts or consumables and amount spent on miscellaneous. Take a record of 14 years of past procurement made by a case study, Federal Institute of Industrial Research Oshodi (FIIRO) in Lagos, Nigeria were collected for testing the models developed to find the ratio of contributions of each strategic decision in yearly budget using normalized ratio. Using normalized ratio makes the models simple and not burdensome.

\subsection{Strategic Decisions for Model Development}

In this research for proper budgeting, three strategic decisions were identified for successful equipment procurement. They are Machine (Mc); Spare parts (SPc); and Miscellaneous (MIc) costs.

\subsection{Strategic Decisions and Acronyms}

The strategic decisions and their acronyms used in this study are:

Machine cost

Spare parts cost

Miscellaneous cost and

Total yearly Budget

Where $=(1,2,3 \ldots \mathrm{n}) \mathrm{yr}$

These strategic decisions are being used in the model to know exactly the amount that will be allotted to each of them and the miscellaneous cost which is extra cost. 


\subsection{Model Development}

Contribution of each strategic decision to yearly budget for any year, is as shown in equations 1-3.

For any year

Machines cost $=\quad$ (i)

Spare parts cost

$=$

Miscellaneous cost

$=$

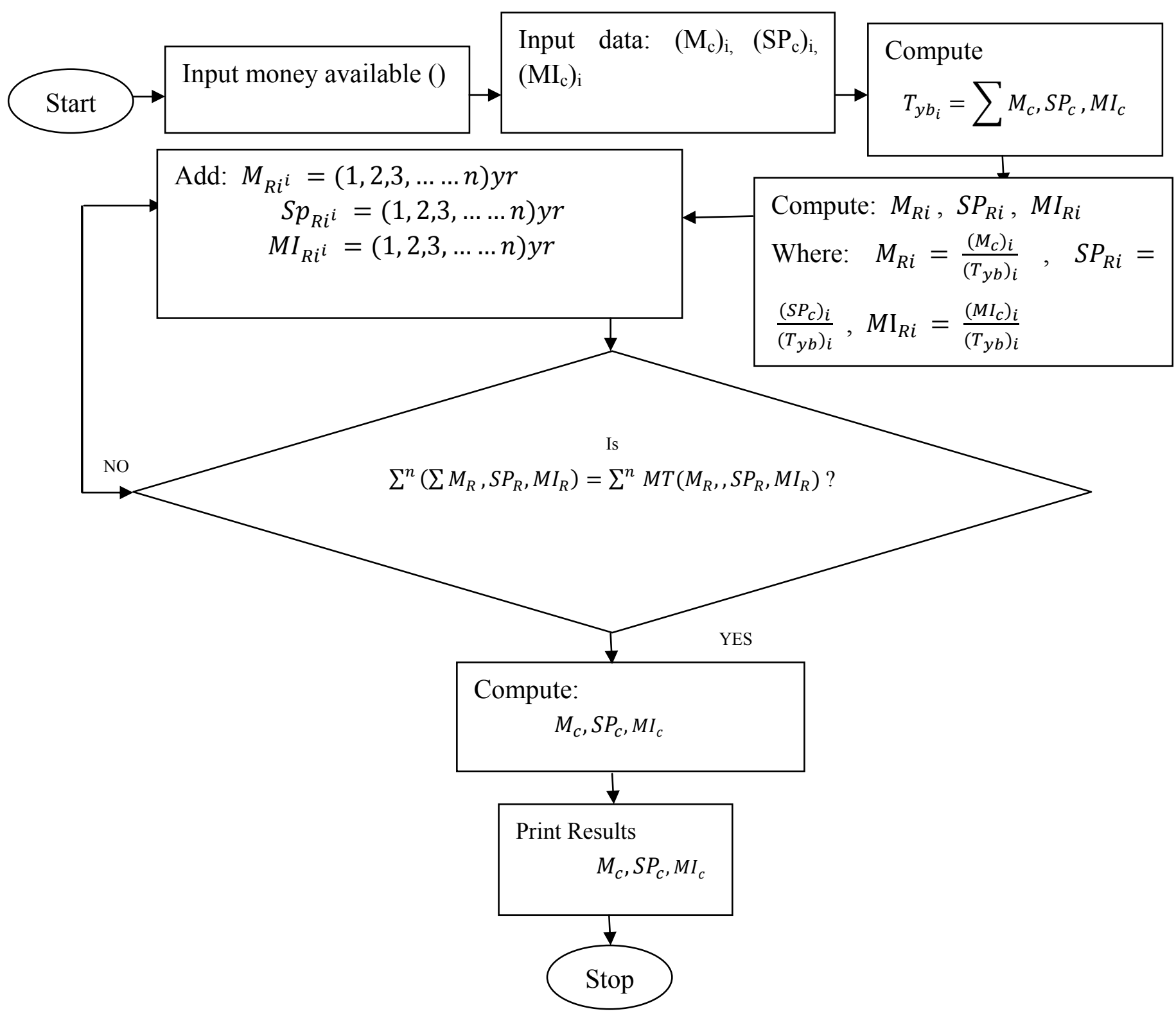

Figure 1. Flow chat for models developed 
Table 1. Available data from FIIRO: Year (2000-2012)

\begin{tabular}{lllll}
\hline YEAR & $\mathrm{M}_{\mathrm{c}}$ & $\mathrm{SP}_{\mathrm{c}}$ & $\mathrm{MI}_{\mathrm{c}}$ & TOTAL \\
\hline 2000 & $9,400.000$ & $6,200.000$ & $1,130.000$ & $16,730.000$ \\
2001 & $1,100.000$ & $7,300.000$ & $1,300.000$ & $9,700.000$ \\
2002 & $1,180.000$ & $7,900.000$ & $1,400.000$ & $10,480.000$ \\
2003 & $1,240.000$ & $8,300.000$ & $1,460.000$ & $11,000.000$ \\
2004 & $1,350.000$ & $8,900.000$ & $1,610.000$ & $11,860.000$ \\
2005 & $1,390.000$ & $9,400.000$ & $1,620.000$ & $12,410.000$ \\
2006 & $1,430.000$ & $9,900.000$ & $1,630.000$ & $12,960.000$ \\
2007 & $1,470.000$ & $10,400.000$ & $1,640.000$ & $13,510.000$ \\
2008 & $1,510.000$ & $10,900.000$ & $1,650.000$ & $14,060.000$ \\
2009 & $1,550.000$ & $11,400.000$ & $1,660.000$ & $14,610.000$ \\
2010 & $1,590.000$ & $11,900.000$ & $1,670.000$ & $15,160.000$ \\
2011 & $1,630.000$ & $12,400.000$ & $1,680.000$ & $15,710.000$ \\
2012 & $1,670.000$ & $12,900.000$ & $1,690.000$ & $16,260.000$ \\
2013 & $1,690.000$ & $13,100.000$ & $1,700.000$ & $16,490.000$ \\
\hline & $28,200.000$ & $140,900.000$ & $21,840.000$ & $190,940.000$ \\
\hline
\end{tabular}

Source: FIIRO, 2013

\subsection{Developed Models Application Sample for Allotting Ratio for Budget Available Yearly}

2.4.1 Manual Computation for Year 2000, the First Year (Year 1)

Ratio of machines contribution to budget of year 2000

Ratio of spare parts contribution to budget of year 2000

Ratio of Miscellaneous contribution to budget of year 2000

This computation was carried out for each year from year 2000 to 2013, the summary of this computation results is as shown in Table 2 under results.

Table 2. Results summary for models application from 2000 to 2013 for allotting ratio

\begin{tabular}{|c|c|c|c|c|c|}
\hline $\mathrm{S} / \mathrm{NO}$ & YEAR & $\begin{array}{l}\text { Machine } \\
\left(\mathrm{M}_{\mathrm{R}}\right)\end{array}$ & Ratio & $\begin{array}{lll}\text { Spare } & \text { part } & \text { Ratio } \\
\left(\mathrm{SP}_{\mathrm{R}}\right) & & \end{array}$ & $\begin{array}{l}\text { Miscellaneous } \\
\left(\mathrm{MI}_{\mathrm{R}}\right)\end{array}$ \\
\hline 1 & 2000 & 0.5619 & & 0.3706 & 0.0675 \\
\hline 2 & 2001 & 0.1134 & & 0.7526 & 0.1340 \\
\hline 3 & 2002 & 0.1126 & & 0.7538 & 0.1336 \\
\hline 4 & 2003 & 0.1127 & & 0.7545 & 0.1327 \\
\hline 5 & 2004 & 0.1138 & & 0.7504 & 0.1358 \\
\hline 6 & 2005 & 0.1120 & & 0.7575 & 0.1305 \\
\hline 7 & 2006 & 0.1103 & & 0.7639 & 0.1258 \\
\hline 8 & 2007 & 0.1088 & & 0.7698 & 0.1214 \\
\hline 9 & 2008 & 0.1074 & & 0.7752 & 0.1174 \\
\hline 10 & 2009 & 0.1061 & & 0.7803 & 0.1136 \\
\hline 11 & 2010 & 0.1049 & & 0.7850 & 0.1102 \\
\hline 12 & 2011 & 0.1038 & & 0.7893 & 0.1069 \\
\hline
\end{tabular}




\begin{tabular}{lllll}
\hline 13 & 2012 & 0.1027 & 0.7934 & 0.1039 \\
14 & 2013 & 0.1025 & 0.7944 & 0.1031 \\
\hline & TOTAL & 1.9729 & 10.3907 & 1.6364 \\
\hline & Average Ratio & 0.1518 & 0.7993 & 0.1259 \\
\hline
\end{tabular}

These average ratios were used in allotting the available budget for all the strategic decisions. The summation of these strategic decisions will stand as the denominator. On yearly basis, the ratio will be recomputed due to new information received.

\section{Results and Discussion}

Assuming 5,500.000 was given as the available money; the money should be optimally allotted to the strategic decisions (i.e. Machine, Spare part and the miscellaneous costs), to know the exact amount that would be spent on each of them. The computation is as follows:

Table 3. Results for allotting available 5,500.000 for equipment procurement in the year 2014

\begin{tabular}{llllll}
\hline $\mathrm{S} / \mathrm{N}$ & $\begin{array}{l}\text { Strategic Decisions } \\
\text { considered }\end{array}$ & Computation & Results (\#) & $\begin{array}{l}\text { US Dollar Equivalent } \\
(170 / \text { dollar })\end{array}$ \\
\hline 1 & $\begin{array}{lllll}\text { Machine, Spare part } \\
\text { and Miscellaneous }\end{array}$ & $\mathrm{SP}_{\mathrm{c}}$ and & $\mathrm{M}_{\mathrm{c},}$ & $\mathrm{M}_{\mathrm{c}}=775,067.86$ & $\mathrm{MI}_{\mathrm{c}}=4,559.72$ \\
& $\mathrm{SP}_{\mathrm{c}}=4,082,060.71$ & $\mathrm{SP}_{\mathrm{c}}=24,012.12$ \\
& & & $\mathrm{MI}_{\mathrm{c}}=642,871.43$ & $\mathrm{MI}_{\mathrm{c}}=3,781.60$ \\
\hline
\end{tabular}

The computation above for each of the strategic decisions shows the amount that would be spent on them. Spare part has the highest amount since it is consumables, and it is also used for the repair or replacement of failed parts, therefore it has the highest inventory.

\subsection{Application of Scenario Model for Allotting Available Money for Equipment Procurement in FIIRO, 2015}

In FIIRO 2015, assuming Six million three hundred and fifty thousand $(6,350.000)$ was made available for equipment procurement for the year 2015, the model used is as follows:

$\sum M_{c}, S P_{c}, M I_{c}=\mathrm{Tr}$

$$
\begin{aligned}
& M_{c}=\frac{M_{R}}{T_{R}} \times M_{a v} \\
& S P_{c}=\frac{S P_{R}}{T_{R}} \times M_{a v} \\
& M I_{c}=\frac{M I_{R}}{T_{R}} \times M_{a v}
\end{aligned}
$$

$$
\begin{aligned}
\text { Where } M_{R} & =\text { Machine Ratio } \\
S P_{R} & =\text { Spare part Ratio } \\
M I_{R} & =\text { Miscellaneous Ratio } \\
T_{R} & =\text { Total Ratio } \\
M_{a v} & =\text { Available Money }
\end{aligned}
$$

$\sum(1.9729,10.3907,1.6364)=14$

$$
\begin{gathered}
M_{c}=\frac{1.9729}{14} \times 6,350,000 \\
=894,851.07
\end{gathered}
$$




$$
\begin{aligned}
S P_{c}= & \frac{10.3907}{14} \times 6,350,000 \\
& =4,712,924.64 \\
M I_{C}= & \frac{1.6364}{14} \times 6,350,000 \\
& =742,224.29
\end{aligned}
$$

\begin{tabular}{|c|c|c|c|c|}
\hline $\mathrm{S} / \mathrm{N}$ & $\begin{array}{l}\text { Strategic } \\
\text { Decisions } \\
\text { considered }\end{array}$ & Computation & Results (\#) & $\begin{array}{l}\text { US Dollars Equivalent } \\
\text { (170/dollar) }\end{array}$ \\
\hline 1 & $\begin{array}{l}\text { Machine, Spare } \\
\text { part and } \\
\text { Miscellaneous } \\
\text { costs }\end{array}$ & $\begin{array}{ll}\text { Compute: } & \mathrm{M}_{\mathrm{c}} \\
\mathrm{SP}_{\mathrm{c}} \text { and } & \mathrm{MI}_{\mathrm{c}} \\
\mathrm{SP}_{\mathrm{c}} & \end{array}$ & $\begin{array}{l}\mathrm{M}_{\mathrm{c}}=894,851.07 \\
\mathrm{SP}_{\mathrm{c}}=4,712,924.64 \\
\mathrm{MI}_{\mathrm{c}}=742,224.29\end{array}$ & $\begin{array}{l}\mathrm{M}_{\mathrm{c}}=5,263.83 \\
\mathrm{SP}_{\mathrm{c}}=27,723.09 \\
\mathrm{MI}_{\mathrm{c}}=4,366.03\end{array}$ \\
\hline
\end{tabular}

Table 4. Results for scenario for allotting available 6,350.000 for equipment procurement in the year 2015

The amount allotted for machine, spare part and miscellaneous cost in the year 2015 are: 894,851.07, 4,712,924.64 and 742,224.29 respectively. The amount allotted for these strategic decisions would be spent for equipment procurement, based on the competing strategic decisions.

\section{Conclusion}

In this study, the model developed gives a concise and adequate method for dispensing available budget on future events based on past and present events and the strategic decisions under the redundant of accessory cost. The method was made flexible to attend to this scenario for budget allocation in equipment procurement and the developed model is applicable to small, medium and large scale industries in which the equipment budgeting affects. Their production in developing and developed countries.

\section{References}

Akinnuli, B. O. (2008). Development of Software for Machinery Budgeting using Exponential Smoothening Model. Nigeria Journal of Engineering Management, 4(2), 16-20.

Bernstein, S. J., Mellon, W. G., \& Hoxie, L. E. (2005). The Multi-Dimensional Allocation of Social Resources. The Journal of Socio-Economic Planning Spectrum.

Blin, J. M. (1991). A general formulation of the multi-attribute Decision Problem: Concepts and Solution of Management. North Western University Working Paper, 101-172.

Bolton, R. A. (2002). System Contracting - A New Purchasing Techniques. American Management Association.

Brand, G. T. (1999). Industrial Buying Decisions “London, Associated Business Programmes Ltd” (p. 134).

Cliché, P., Côté, L., \& Savard, J. F. (2012). Encyclopedic Dictionary of Public Administration. Retrieved from http://www.dictionnaire.enap.ca/Dictionnaire/en/home.aspx

Dyer, J., Geoffrion, A., \& Feinberg, A. (2003). A Mathematical Model of Multi-Dimensional Evaluation. Decision Making, and Social Interaction, 20, 382-389.

Fabrycky, W. J. (2002). Procurement and Inventory Theory. State University Office of Engineering Research, 3.

George, T. (2004). Business Investment Management. Machinery and Allied Products Institute, 10-13.

Hayes, F. A., \& Renard, G. A. (1993). Evaluating Purchasing Performance. American Management Association, $66,125$.

Hunt, D. (1973). Costs Determination Form Power and Machinery Management. In Laboratory Manual and Workshop (6th ed.).

Hurwicz, L. (1973). The Design Mechanisms for Resources Allocation. American Economic Review Papers and Proceedings. 
Iwarere, H. T. (2007). Comtemporary Management Accounting (pp. 178-180). Obatedo-iloko.

Osmond, V. (2009). How Does Budgeting Affect Inventory Control and Personnel. Retrieved from http://www.chron.com

Peter, B. (2007). Transforming Financial Planning in Small and Medium Sized Companies. Beyong Budgetting Round Table, 2007. Retrieved from http://www.bbrt.org

\section{Copyrights}

Copyright for this article is retained by the author(s), with first publication rights granted to the journal.

This is an open-access article distributed under the terms and conditions of the Creative Commons Attribution license (http://creativecommons.org/licenses/by/3.0/). 